\title{
Tolerance of juvenile Mytilus galloprovincialis to experimental seawater acidification
}

\author{
M $^{\mathrm{a}}$ José Fernández-Reiriz ${ }^{1, *}$, Pedro Range ${ }^{2}$, Xosé Antón Álvarez-Salgado ${ }^{1}$, \\ Joaquin Espinosa ${ }^{3}$, Uxio Labarta ${ }^{1}$ \\ ${ }^{1}$ Consejo Superior de Investigaciones Científicas, Instituto de Investigaciones Marinas (CSIC-IIM), Eduardo Cabello 6, \\ 36208 Vigo, Spain \\ ${ }^{2}$ Centro de Ciências do Mar (CCMAR), Universidade do Algarve, Campus de Gambelas, 8005-139 Faro, Portugal \\ ${ }^{3}$ Universidad de Santiago de Compostela, Departamento de Fisiología, Facultad de Farmacia, Santiago de Compostela, Spain
}

\begin{abstract}
Coastal ocean acidification is expected to interfere with the physiology of marine bivalves. In this work, the effects of acidification on the physiology of juvenile mussels Mytilus galloprovincialis were tested by means of controlled $\mathrm{CO}_{2}$ perturbation experiments. The carbonate chemistry of natural (control) seawater was manipulated by injecting $\mathrm{CO}_{2}$ to attain 2 reduced $\mathrm{pH}$ levels: -0.3 and $-0.6 \mathrm{pH}$ units as compared with the control seawater. After $78 \mathrm{~d}$ of exposure, we found that the absorption efficiency and ammonium excretion rate of juveniles were inversely related to $\mathrm{pH}$. Significant differences among treatments were not observed in clearance, ingestion and respiration rates. Coherently, the maximal scope for growth and tissue dry weight were observed in mussels exposed to the $\mathrm{pH}$ reduction $\Delta \mathrm{pH}=-0.6$, suggesting that $M$. galloprovincialis could be tolerant to $\mathrm{CO}_{2}$ acidification, at least in the highly alkaline coastal waters of Ria Formosa (SW Portugal).
\end{abstract}

KEY WORDS: Ocean acidification · Blue mussels · Feeding behaviour · Physiological energetics · Absorption bivalves $\cdot$ Metabolism

\section{INTRODUCTION}

The dissolution of anthropogenic $\mathrm{CO}_{2}$ in the oceans has dramatically altered the inorganic carbon chemistry of seawater by reducing the saturation of $\mathrm{CO}_{3}{ }^{2-}$ and the $\mathrm{pH}$ (Feely et al. 2004). The decline of $\mathrm{CO}_{3}{ }^{2-}$ concentration has detrimental effects on marine calcifiers (Orr et al. 2005, Gazeau et al. 2007, Miller et al. 2009), whereas changes in $\mathrm{pCO}_{2}$ and $\mathrm{pH}$ are expected to affect the physiology of all marine life (Fabry et al. 2008, Melzner et al. 2009).

Coastal zones are considered highly productive hotspots, contributing $>90 \%$ to the marine living resources currently harvested (Pauly et al. 2002). These nearshore areas are characterized by a large spatial and temporal variability in the carbonate chemistry as compared with the open ocean. Oceanic (e.g. upwelling) and continental (e.g. river discharge) processes may lead to a coastal zone with low oxygen waters that are supersaturated with $\mathrm{CO}_{2}$ and have reduced $\mathrm{CO}_{3}{ }^{2-}$ and pH (Salisbury et al. 2008, Koch \& Gobler 2009). On the other hand, the alkalinity of continental waters may be a major contributor to the $\mathrm{CO}_{3}{ }^{2-}$ concentration in the coastal zone. Naturally elevated alkalinity may prevent or delay $\mathrm{CaCO}_{3}$ under-saturation in coastal waters under future ocean acidification scenarios (Fernández-Reiriz et al. 2011, Range et al. 2011).

Our current understanding of the effect of future ocean acidification on the physiological and ecological fitness of marine organisms is incomplete. While growing empirical evidence from $\mathrm{CO}_{2}$ perturbation experiments suggests that several taxa might react quite sensitively to ocean acidification (e.g. Michae- 
lidis et al. 2005), others seem to be surprisingly tolerant (e.g. Gutowska et al. 2008). Naturally acidified habitats allow to investigate organisms and communities under high $\mathrm{pCO}_{2}$ conditions in general (e.g. Hall-Spencer et al. 2008, Fabricius et al. 2011) and mussels in particular (Thomsen et al. 2010, RodolfoMetalpa et al. 2011). Multi-generation experiments can also contribute important evidence about the sensitivity and adaptation potential of a given species. Considering the scarcity of that type of study, an alternative approach is to look at indicators for animal performance during long-term $\mathrm{CO}_{2}$ perturbation experiments (Melzner et al 2009).

Bivalves dominate the macrofauna of many estuaries and coastal embayments. Understanding their physiological behaviour is crucial for determining their productivity and energy flows. Changes in environmental variables can affect physiological processes in bivalves, modifying their influence on the ecosystem. These effects need to be evaluated in an integrated way, given the important role these organisms play in terms of ecological structure and their value as economic resources for fisheries and aquaculture in many coastal areas. The potential of significant ecological and economic consequences arising from the effects of ocean acidification on bivalves and the need for further research on commercially important species has been explicitly recognized (Kleypas et al. 2006, Fabry et al. 2008, Cooley \& Doney 2009).

Scientific research on the effects of seawater acidification on bivalves has been increasing rapidly in recent years. Most previous studies have focused on growth and calcification of the shell (Berge et al. 2006, Gazeau et al. 2007, Miller et al. 2009, Gazeau et al. 2010, Thomsen \& Melzner 2010, Range et al. 2011), feeding behaviour, reproduction and metabolism (Michaelidis et al. 2005, Beesley et al. 2008, Saphoerster 2008). Fernández-Reiriz et al. (2011) studied the physiological energetics of juvenile clams Ruditapes decussates in high $\mathrm{pCO}_{2}$ conditions and observed reduced ingestion combined with increased excretion, which is generally associated with a reduced energy input and will likely contribute to a slower growth of the clams in future acidification scenarios. There are, however, no previous studies examining the scope for growth (SFG) of bivalves under conditions of increased $\mathrm{pCO}_{2}$. Anestis et al. (2010) studied the response of physiological parameters of Mytilus galloprovincialis to increasing seawater temperature, according to current scenarios of climatic change. They found that the SFG values became negative at temperatures higher than $24^{\circ} \mathrm{C}$, probably associated with a significant reduction in the clear- ance rate. Other recent studies have shown that current and future increases in $\mathrm{pCO}_{2}$ may deplete or alter the composition of shellfish populations in coastal ecosystems (Bibby et al. 2008, Kurihara 2008, Miller et al. 2009, Talmage \& Gobler 2009).

We target the mussel Mytilus galloprovincialis. This species is distributed worldwide dominates the extensive cultures of the Galician rías (NW Spain). The experiments were conducted on juvenile mussels, which represent an important life stage for shellfish populations, as reductions in the growth and survival of seed have the potential to translate into declines of adult populations (Arnold 2008). We focused on analyzing the effects of seawater acidification caused by increasing concentrations of $\mathrm{pCO}_{2}$, as predicted by current scenarios of climate change. Three levels of $\mathrm{pH}$ were tested: a natural (control) level and 2 levels of reduced $\mathrm{pH}$, by -0.3 and $-0.6 \mathrm{pH}$ units, relative to the control seawater. The response of the mussels was measured after $78 \mathrm{~d}$ of exposure to the 3 contrasting conditions, in terms of their key physiological parameters: in particular (1) clearance and ingestion rate; (2) absorption efficiency; (3) oxygen consumption; (4) ammonia excretion; (5) oxygen to nitrogen (O:N) ratio and (6) scope for growth (SFG).

\section{MATERIALS AND METHODS}

\section{Biological material}

Juvenile Mytilus galloprovincialis were obtained from a mussel raft in the Ría de Ares-Betanzos $\left(43^{\circ} 23^{\prime}\right.$ 23.01" N, $8^{\circ} 17^{\prime} 27.29^{\prime \prime}$ W). Between 2007 and 2010, the physicochemical characteristics of seawater at this site were monitored with weekly frequency $(\mathrm{n}=174 \mathrm{ob}$ servations). The ranges of recorded values were 30.46 to 35.46 for salinity, 11.08 to $22.35^{\circ} \mathrm{C}$ for temperature, 81 to $149 \%$ for dissolved oxygen saturation and 7.7 to 8.4 for $\mathrm{pH}$. At the beginning of the experiment, the mussels were approximately 6 mo old, ranging from 10 to $15 \mathrm{~mm}$ shell length, $6.9 \pm 0.7 \mathrm{mg}$ dry weight $\left(100^{\circ} \mathrm{C}, 24 \mathrm{~h}\right)$ and $23.2 \pm 0.4 \%$ ash $\left(450^{\circ} \mathrm{C}, 24 \mathrm{~h}\right)$.

\section{pH exposure system}

The rearing system was installed in an experimental bivalve hatchery in Tavira, Portugal $\left(37^{\circ} 7^{\prime}\right.$ $17.73^{\prime \prime} \mathrm{N}, 7^{\circ} 37^{\prime} 12.19^{\prime \prime} \mathrm{W}$ ), operated by the National Institute of Biological Resources (INRB, I.P./LIPIMAR). Seawater was pumped from the Ría Formosa lagoon, passed through a sand filter and aer- 
ated for 2 to $3 \mathrm{~d}$ before entering the rearing system, to ensure adequate oxygenation and stable $\mathrm{pH}$ during the exposure. Three levels of $\mathrm{pH}$ were tested: natural seawater (control; $\Delta \mathrm{pH}=0$ ) and 2 levels of reduced $\mathrm{pH}(\Delta \mathrm{pH}=-0.3$ and $\Delta \mathrm{pH}=-0.6$ units as compared with the control). Each level of $\mathrm{pH}$ had a separate 2501 header tank and pump, supplying 3 replicate 151 plastic exposure tanks. The seawater supply to the exposure tanks was manually regulated using PVC valves. A flow-through system was used to minimize any interference from the metabolic waste products of the mussels. Excess water overflowed so that, on average, the volume in each tank was renewed 8 times per day.

Carbonate chemistry of seawater was manipulated in the reduced $\mathrm{pH}$ treatments $(\Delta \mathrm{pH}=-0.3$ and $\Delta \mathrm{pH}=$ -0.6 units) by diffusing pure $\mathrm{CO}_{2}$ in closed reactors (Aqua Medic reactor 1000) installed before the exposure tanks. The gas flux from the pure $\mathrm{CO}_{2}$ tanks to the reactors was controlled through a pH-stat system (Aqua Medic AT Control) by opening or closing a solenoid valve when the $\mathrm{pH}$ readings in the exposure tanks deviated from the predetermined set-points by $\pm 0.1 \mathrm{pH}$ units.

The exposure started on 21 December 2009, when the 9 tanks were stocked with 200 juvenile mussels each. The $\mathrm{pH}$ of the acidified treatments was gradually reduced to the target values over the following week. The mussels were fed with a 1:1 mixture of 2 microalgae strains, Tahitian Isochrysis aff. galbana (TISO) and Chaetoceros calcitrans, supplied in continuous flow to each tank by a peristaltic pump (ISMATEC MPC Process) to maintain a concentration of 19 to 20 cells $\mathrm{ll}^{-1}$, equivalent to a total particulate matter load of $3.84 \mathrm{mg} \mathrm{l}^{-1}$ with $60 \%$ organic content. The seawater used for the preparation of the diet was filtered through a cartridge filter system with an effective pore size of $1 \mu \mathrm{m}$ and pre-treated with ultraviolet light. The diet was maintained in an aerated tank to generate a homogeneous mixture and prevent sedimentation. All the physiological experiments were done with the same seawater supply and diet used during the exposure, thus ensuring that the relevant environmental conditions (temperature, salinity, $\mathrm{pH}$ and food supply) were maintained. Feeding was stopped $24 \mathrm{~h}$ before starting the physiological measurements.

\section{Monitoring of the physical-chemical variables of seawater}

Temperature, salinity and $\mathrm{pH}$ of seawater were continuously monitored in the exposure tanks dur- ing the $78 \mathrm{~d}$ of the experiment using dedicated electrodes and the data-logger function of the controller. Automatic readings were validated against regular manual determinations with a calibrated YSI 556 multi-probe. The $\mathrm{pH}$ electrodes were standardized against Tris seawater buffers (ionic strength of $0.7 \mathrm{M}$ ) and readings were expressed in the total scale $\left(\mathrm{pH}_{\mathrm{T}}\right)$. Salinity readings were calibrated with an AutoSal salinometer using IAPSO standard seawater.

Water samples were collected on 8 February 2010. Dissolved oxygen was determined by the Winkler method. Determinations of total alkalinity (TA) were done by automatic titration with $\mathrm{HCl}$ past the endpoint of $\mathrm{pH}$ 4.5. Dissolved inorganic carbon (DIC), partial pressure of $\mathrm{CO}_{2}$ in seawater $\left(\mathrm{pCO}_{2}\right)$ and the $\mathrm{CaCO}_{3}$ saturation state for calcite $(\Omega \mathrm{cal})$ and aragonite $(\Omega$ ara) were calculated from in situ temperature, salinity, $\mathrm{pH}$ and $\mathrm{TA}$, according to the procedures described by Range et al. (2011).

\section{Physiological experiments}

The feeding and digestive behaviour and metabolic activity of Mytilus galloprovincialis were determined at the beginning of the exposure (initial), under natural $\mathrm{pH}$ conditions, and after $78 \mathrm{~d}$ of exposure (09 March 2010) at each of the 3 levels of $\mathrm{pH}$ considered $(\Delta \mathrm{pH}=0.0 ; \Delta \mathrm{pH}=-0.3 ;$ and $\Delta \mathrm{pH}=-0.6$ units). First physiological measurements (on 21 December 2009) were performed after the individuals had been maintained for $12 \mathrm{~h}$ under natural $\mathrm{pH}$ conditions. Mortalities during the exposure varied from $5 \%$ to $10 \%$ and the final shell length ranged from 11.5 to $32 \mathrm{~mm}$. Neither of these variables differed significantly among $\mathrm{pH}$ treatments.

After 78 days of exposure, 2 size-classes were distinguished, according to the modal size class (small: 19 to $21 \mathrm{~mm}$ and large: 22 to $29 \mathrm{~mm}$ shell length). The physiological determinations of clearance, ingestion, respiration and excretion rates were determined using 3 distinct pools of 5 (large) or 10 (small) individuals for each combination of $\mathrm{pH}$ level and size class. Individuals in each pool were randomly selected from the same exposure tank. A minimum of 3 ind. from each pool used in the physiological determinations on Days 0 and 78 were subsequently sacrificed for determination of tissue (drying: $100^{\circ} \mathrm{C}, 24 \mathrm{~h}$ ) and organic dry weight (DW) (combustion: $450^{\circ} \mathrm{C}, 24 \mathrm{~h}$ ). In all determinations, the physiological rates were also referred to the unit of organic weight (specific rates). 


\section{Clearance (CR) and ingestion rates (IR)}

The CR was estimated from the reduction in suspended particles concentration, measured as volume of particles $\left(\mathrm{mm}^{3} \mathrm{l}^{-1}\right)$, between the water surrounding the individuals and the outflow of the experimental chamber following Filgueira et al. (2006). The mussels (see the Physiological experiments section) were placed in a cylindrical chamber of $300 \mathrm{ml}$ with a water inflow in the lower part and water outflow in the upper opposite side The mussels were placed in the chambers in such a way that the input flow was directed to the inhalant aperture and that the exhalant aperture was directed toward the water outflow, thus preventing re-filtration processes. For each $\mathrm{pH}$ level, 2 chambers without mussels served as blanks for the calculation of the CR. The ingestion rate (IR) was calculated as the product of CR and food concentration.

\section{Absorption efficiency}

Absorption efficiency was estimated by determining the organic and inorganic content of the food and the faeces following the method of Conover (1966). Representative samples of the diet were collected during the experiments and the absorption efficiency was calculated for a given pool of mussels by collecting the faeces in each experimental chamber. Samples of food and faeces were filtered through pre-combusted, pre-weighed Whatman GF/C membranes. Filters were rinsed with isotonic ammonium formate, dried to a constant weight at $80^{\circ} \mathrm{C}$, and then weighed and combusted at $450^{\circ} \mathrm{C}$ for $3 \mathrm{~h}$. The filters were weighed again to estimate the organic and inorganic fraction contained in the food and faeces.

\section{Respiration rate $\left(V_{\mathrm{O} 2}\right)$}

Respiration rates were determined by incubating the mussels in sealed $100 \mathrm{ml}$ Erlenmeyer flasks containing seawater at each pH studied (see the Physiological experiments section). Temperature was maintained during the determinations by immersing the flasks in an isothermal bath. Two Erlenmeyer without animals were used as a control for each treatment. The mussels were left undisturbed until most of them had their valves opened, or at least for 45 to $60 \mathrm{~min}$. Subsequently, oxygen measurements were started using a manual probe (HACH HQ40). The depletion of oxygen in the chamber, due to respiration by the mussels, was recorded for 30 to $60 \mathrm{~min}$, depending on the size class. The measurements were stopped before the oxygen concentration dropped below $30 \%$, relative to control Erlenmeyer without mussels. Respiration rates were calculated from the difference in concentration between the chambers with and without animals.

\section{Ammonia excretion rate $\left(V_{\mathrm{NH} 4-\mathrm{N}}\right)$}

Ammonia excretion rate was determined after placing the mussels in open Erlenmeyer flasks with $250 \mathrm{ml}$ of filtered seawater $(0.2 \mu \mathrm{m}$ Millipore membranes) at each pH studied (see the Physiological experiments section). Temperature was maintained during the determinations by immersing the flasks in an isothermal bath. Two Erlenmeyer without mussels were used as a control for each treatment. After 90 min, water samples were collected from each flask and frozen to $-20^{\circ} \mathrm{C}$ until analysis using the phenolhypochlorite method (Solorzano 1969). Ammonia excretion rates were calculated from the difference in ammonia concentration between the chambers with and without animals. The ratio of oxygen consumed to nitrogen excreted $(\mathrm{O}: \mathrm{N})$ was computed by atomic equivalents, according to Widdows (1985).

\section{Scope for growth (SFG)}

SFG is defined as the fraction of the absorbed energy available for somatic or gametogenic growth once metabolic requirements have been met (Widdows 1985). Accordingly, SFG was computed following the equation for energetic balance developed by Winberg (1960) and Ivlev (1966),

$$
\mathrm{SFG}=I-F a e-M=\mathrm{AR}-M
$$

where $I$ is the ingested energy, Fae is the energy loss in the faeces, $M$ summarizes the metabolic expenditure plus the energy loss due to excretion and AR is the absorbed energy, computed as the product of ingestion rate and absorption efficiency (Labarta et al. 1997).

The following energy conversion factors were used, as described by Bayne et al. (1985):

$1 \mathrm{mg} P O M=23.5 \mathrm{~J}$

$1 \mathrm{ml} \mathrm{O}=20.36 \mathrm{~J}$

$1 \mu \mathrm{g} \mathrm{NH}_{4}-\mathrm{N}=0.0249 \mathrm{~J}$

\section{Statistical analysis}

The effects of $\mathrm{pH}$ and size on the variation of physiological rates (clearance and ingestion rates, ab- 
sorption efficiency and metabolism) and dry weight were compared using 2-factor analyses of variance (ANOVA). Homogeneity of variance was confirmed by means of Bartlett's tests. When appropriate, multiple comparisons for means were carried out on significant main effects and interactions using Tukey's tests (Snedecor \& Cochran 1980, Zar 1984). Differences between means were considered statistically significant for $\mathrm{p}<0.05$.

\section{RESULTS}

\section{Physical-chemical characteristics of seawater}

On average, the planned differences in $\mathrm{pH}$ between control and acidified treatments were achieved (Table 1). During the last $5 \mathrm{wk}$ of exposure, a decreasing trend was apparent in the reduced $\mathrm{pH}$ treatments (Fig. 1), which might have been caused by slight drift in the reference electrodes. Salinity values consistently decreased during the exposure (Fig. 1), from 30 to 26. Seawater temperature varied between 15 and $20^{\circ} \mathrm{C}$, while TA ranged from 3542 to $3554 \mu \mathrm{mol} \mathrm{kg}{ }^{-1}$. Dissolved oxygen in the exposure tanks consistently exceeded $96 \%$.

\section{Dry weight and physiological parameters}

The DW and physiological parameters determined for the juvenile mussels before the exposure are shown in Table 2. At the end of the experiments, size and $\mathrm{pH}$ were both significantly correlated with the tissue DW (Table 2; 2-way ANOVA, Tukey's test, p < 0.01 ) resulting in the highest DW in the 22 to $29 \mathrm{~mm}$ mussel size class in the $\Delta \mathrm{pH}=-0.6$ treatment. Clearance, ingestion, metabolic rates and $\mathrm{O}: \mathrm{N}$ index were significantly related to the mussel size, but not to the pH treatment (Tables $2 \& 3$; Tukey's test, p $<0.01$, 2-way ANOVA).
$\mathrm{pH}$ was the only significant source of variation (2way ANOVA) in absorption efficiency (AE) and ammonia excretion rate $\left(V_{\mathrm{NH} 4-\mathrm{N}}\right)$ of mussels (Table 3$)$. Similarly to the DW, AE and $V_{\mathrm{NH} 4-\mathrm{N}}$ were inversely related to $\mathrm{pH}$, for both size classes of mussels, with minimal values for the control $\mathrm{pH}$ and maximal values for $\Delta \mathrm{pH}=-0.6$. There were no significant differences in relation to size $(\mathrm{p}>0.05)$ for these variables.
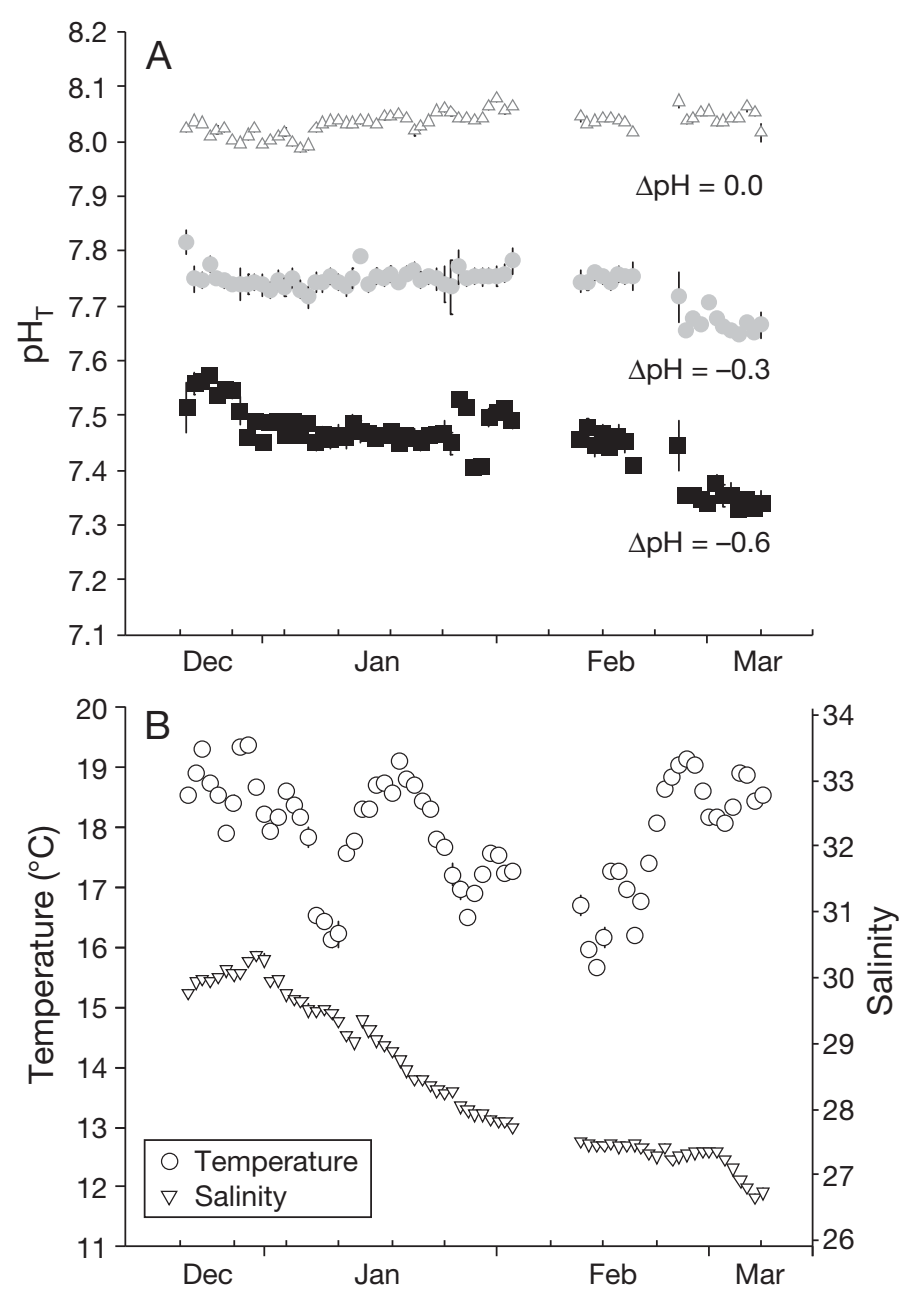

Fig. 1. Daily values (mean $\pm \mathrm{SE}$ ) for $(\mathrm{A}) \mathrm{pH}$ and (B) temperature and salinity of seawater during the $78 \mathrm{~d}$ of exposure

Table 1. Seawater carbonate chemistry variables (mean $\pm \mathrm{SE}, \mathrm{n}=3$ ): $\mathrm{pH}$ values (total scale) are the average of automatic records during the exposure; $\left(T=17.73 \pm 0.03^{\circ} \mathrm{C}\right)$, salinity $(\mathrm{S}=28.79 \pm 0.01)$ and total alkalinity $(\mathrm{TA})$ were measured on 8 February 2010; dissolved inorganic carbon (DIC); partial pressure of $\mathrm{CO}_{2}$ in seawater $\left(\mathrm{pCO}_{2}\right)$ and saturation state for calcite $\left(\Omega_{\text {cal }}\right)$ and aragonite $\left(\Omega_{\text {ara }}\right)$ were calculated from in situ temperature, salinity, $\mathrm{pH}$ and TA

\begin{tabular}{|lccccrr}
\hline $\mathrm{pH}$ level & $\mathrm{pH}_{\mathrm{T}}$ & $\begin{array}{c}\mathrm{TA} \\
\left(\mu \mathrm{mol} \mathrm{kg}{ }^{-1}\right)\end{array}$ & $\begin{array}{c}\mathrm{DIC} \\
\left.(\mu \mathrm{mol} \mathrm{kg})^{-1}\right)\end{array}$ & $\begin{array}{c}\mathrm{pCO}_{2} \\
(\mu \mathrm{atm})\end{array}$ & $\Omega_{\text {cal }}$ & $\Omega_{\text {ara }}$ \\
\hline$\Delta \mathrm{pH}=0.0$ & $8.03 \pm 0.01$ & $3549 \pm 2$ & $3303 \pm 3$ & $963 \pm 14$ & $5.53 \pm 0.07$ & $3.58 \pm 0.05$ \\
$\Delta \mathrm{pH}=-0.3$ & $7.74 \pm 0.00$ & $3542 \pm 2$ & $3452 \pm 2$ & $1989 \pm 19$ & $3.03 \pm 0.00$ & $1.96 \pm 0.00$ \\
$\Delta \mathrm{pH}=-0.6$ & $7.48 \pm 0.01$ & $3554 \pm 16$ & $3584 \pm 18$ & $3790 \pm 55$ & $1.72 \pm 0.03$ & $1.11 \pm 0.02$ \\
\hline
\end{tabular}




\section{Scope for growth (SFG)}

The 2-way ANOVA indicated that $\mathrm{pH}$, size and the interaction of both factors all had a significant effect on SFG. The values of SFG were inversely related to $\mathrm{pH}$, for both mussel size classes, with maximal values for $\Delta \mathrm{pH}=-0.6$. There were significant differences in relation to size (Tukey's test, $\mathrm{p}<0.01$ ) for this variable.

\section{DISCUSSION}

Current knowledge about the ecophysiological effects of seawater acidification on different taxonomic groups is limited (Melzner et al. 2009). Pörtner et al. (2004), Fabry et al. (2008) and Pörtner (2008) emphasized that we are only beginning to see the patterns that define tolerance versus sensitivity to future ocean acidification scenarios. Furthermore, Miller et al. (2009) suggested that the biological responses to acidification, especially for calcifying biota, will be species-specific and much more variable and complex than previously reported.

Our study shows that the levels of seawater acidification tested ( $\mathrm{pH}$ reduced by 0.3 and 0.6 units, relative to the natural $\mathrm{pH}$ levels of Ría Formosa lagoon) had no effect on feeding (clearance and ingestion rates) and metabolic rates ( $\left.V_{\mathrm{O} 2}\right)$ of juvenile Mytilus galloprovincialis. In contrast, the $\mathrm{pH}$ reductions tested increased $\mathrm{AE}$, ammonia excretion $\left(V_{\mathrm{NH} 4-\mathrm{N}}\right)$ and organic tissue weight (see Table 2). The physiological energetics values measured in the mussel seed before the experiments were similar to those observed in previous studies (Babarro et al. 2000a, b).

Saphoerster (2008) reported inhibition of filtration activity for the blue mussel Mytilus edulis at elevated concentrations of $\mathrm{CO}_{2}$ (4000 ppm), corresponding to a seawater $\mathrm{pH}$ of 7.2 and severe $\mathrm{CaCO}_{3}$ under saturation. In our previous study with Ruditapes decussatus (Fernández-Reiriz et al. 2011), similar manipulations of seawater carbonate chemistry produced deleterious effects on feeding behaviour (clearance and ingestion rates). Furthermore, the most extreme $\mathrm{pH}$ reduction $(\Delta \mathrm{pH}=-0.7)$ also caused a decrease in metabolic rates and an increase in ammonia excretion. That study also showed a loss of organic tissue weight with decreasing $\mathrm{pH}$.

Other studies have shown deleterious effects of $\mathrm{CO}_{2}$-induced acidification on bivalve molluscs. Bamber (1990), Michaelidis et al. (2005) and Gazeau et al. (2010), among others, recorded suppression of feeding activity and growth, depressed metabolism, increased $\mathrm{N}$ excretion and loss of tissue weight for marine bivalves exposed to reduced seawater $\mathrm{pH}$. It should be noted, however, that significant effects were only observed at $\mathrm{pH}$ values $<7$ or at $\mathrm{pCO}_{2}$ levels which are beyond the worst $\mathrm{CO}_{2}$ emission scenarios.

Table 2. Mytilus galloprovincialis. Physiological parameters (mean \pm SD) of mussel juveniles. No. ind.: total number of individuals used in each physiological determination; CR: clearance rate; IR: ingestion rate; $\mathrm{AE}$ : absorption efficiency; $\mathrm{V}_{\mathrm{O} 2}$ : respiration rate; $V_{\mathrm{NH} 4-\mathrm{N}}$ : ammonia excretion rate; O:N: ratio of oxygen consumed to nitrogen excreted; SFG: scope for growth; OW: organic weight. Means within the same columns with different superscript letters are significantly different $(p<0.05)$. Three distinct pools of 5 (large) or 10 (small) individuals were used for each combination of pH level and size-class; each pool was composed of randomly selected individuals (within each size class) from 1 of the 3 replicate acclimation tanks for each level of $\mathrm{pH}$. The decrease and increase values (\%) in dry weight, $\mathrm{AE}$ and $V_{\mathrm{NH} 4-\mathrm{N}}$ of mussels exposed to $\Delta \mathrm{pH}-0.6$ and $\Delta \mathrm{pH}-0.3 \mathrm{versus}$ $\mathrm{pH}$ control are given in brackets; the 2 values are for each of the 2 size classes (smallest and largest group respectively). Dates are given as dd.mo.yr

\begin{tabular}{|c|c|c|c|c|c|c|c|c|}
\hline Date & $\begin{array}{l}\text { Shell } \\
\text { length } \\
(\mathrm{mm})\end{array}$ & $\begin{array}{c}\text { Dry } \\
\text { weight } \\
\text { (mg) }\end{array}$ & $\begin{array}{l}\text { Ash } \\
(\%)\end{array}$ & $\begin{array}{l}\text { No. } \\
\text { ind. }\end{array}$ & $\begin{array}{c}\mathrm{CR} \\
\left(\mathrm{ml} \mathrm{h}^{-1}\right)\end{array}$ & $\begin{array}{l}\text { CR (specific) } \\
(\mathrm{ml}(\mathrm{mg} \\
\left.\mathrm{OW})^{-1} \mathrm{~h}^{-1}\right)\end{array}$ & $\begin{array}{c}\text { IR } \\
\left(\mu \mathrm{OW} \mathrm{h} \mathrm{h}^{-1}\right)\end{array}$ & $\begin{array}{c}\text { IR (specific) } \\
(\mu \mathrm{g} \text { OW }(\mathrm{mg} \\
\left.\mathrm{OW})^{-1} \mathrm{~h}^{-1}\right)\end{array}$ \\
\hline \multicolumn{9}{|l|}{ Initial } \\
\hline 21.12.09 & $10-15$ & $6.9 \pm 0.8$ & $23.2 \pm 0.4$ & 100 & $158.1 \pm 9.6$ & $11.3 \pm 3.2$ & $97.6 \pm 8.5$ & $5.6 \pm 1.6$ \\
\hline \multicolumn{9}{|l|}{ Exposure } \\
\hline \multicolumn{9}{|l|}{$\Delta \mathrm{pH}=-0.6$} \\
\hline 09.03 .10 & $19-21$ & $23.6 \pm 1.9^{\mathrm{a}}$ & $19.0 \pm 1.9$ & 30 & $322.2 \pm 40.3^{\mathrm{a}}$ & $16.7 \pm 4.3^{\mathrm{a}}$ & $408.9 \pm 32.7^{a}$ & $21.2 \pm 5.4^{\mathrm{a}}$ \\
\hline 09.03 .10 & $22-29$ & $\begin{array}{c}45.4 \pm 5.9^{b} \\
(+10.8 ;+24.9)\end{array}$ & $19.6 \pm 1.0$ & 15 & $841.8 \pm 82.9^{b}$ & $23.3 \pm 4.0^{\mathrm{b}}$ & $1068.2 \pm 60.9^{\mathrm{b}}$ & $29.5 \pm 5.0^{\mathrm{b}}$ \\
\hline \multicolumn{9}{|l|}{$\Delta \mathrm{pH}=-0.3$} \\
\hline 09.03 .10 & $19-21$ & $22.3 \pm 2.1^{\mathrm{c}}$ & $18.4 \pm 0.6$ & 30 & $330.8 \pm 27.4^{\mathrm{a}}$ & $18.3 \pm 3.9^{\mathrm{a}}$ & $357.0 \pm 20.5^{\mathrm{a}}$ & $19.8 \pm 2.8^{\mathrm{a}}$ \\
\hline 09.03 .10 & $22-29$ & $\begin{array}{c}38.8 \pm 3.5^{\mathrm{d}} \\
(+4.4 ;+6.7)\end{array}$ & $21.7 \pm 1.0$ & 15 & $793.2 \pm 78.5^{\mathrm{b}}$ & $25.7 \pm 6.5^{b}$ & $952.7 \pm 78.6^{b}$ & $30.8 \pm 7.8^{b}$ \\
\hline \multicolumn{9}{|l|}{$\Delta \mathrm{pH}=\mathbf{0 . 0}$} \\
\hline 09.03 .10 & $19-21$ & $21.3 \pm 2.8^{\mathrm{e}}$ & $16.6 \pm 0.5$ & 30 & $325.7 \pm 31.4^{\mathrm{a}}$ & $18.4 \pm 2.8^{\mathrm{a}}$ & $367.5 \pm 21.5^{\mathrm{a}}$ & $20.8 \pm 7.6^{\mathrm{a}}$ \\
\hline 09.03 .10 & $22-29$ & $36.3 \pm 2.0^{f}$ & $18.5 \pm 0.8$ & 15 & $850.4 \pm 65.9^{b}$ & $28.6 \pm 4.7^{\mathrm{b}}$ & $1055.4 \pm 55.7^{\mathrm{b}}$ & $35.5 \pm 5.9^{b}$ \\
\hline
\end{tabular}


The responses of bivalves to ocean acidification are complex and suggest a large degree of variability in their sensitivity to this type of perturbation. Talmage \& Gobler (2009) have shown that levels of atmospheric $\mathrm{CO}_{2}$ similar to those predicted for the 21st century may affect some species of bivalves (e.g. Mercenaria mercenaria) more than others (e.g. Crassostrea virginica). Berge et al. (2006) have reported larger growth increments for small Mytilus edulis reared under conditions of increased $\mathrm{pCO}_{2}$ and reduced $\mathrm{pH}$ (by 0.5 units), but attributed the effect to random variation. Furthermore, unchanged or even increased oxygen consumption has been observed for different marine taxa when exposed to acidification (Gutowska et al. 2008, Melzner et al. 2009, Comeau et al. 2010). The response in terms of calcification has also been showed to be more heterogeneous than previously thought. Reduced, conserved or even increased calcification rates under acidified conditions have been measured for different phyla and life stages (Gazeau et al. 2007, 2010, Gutowska et al. 2008, Wood et al. 2008, Ries et al. 2009, Comeau et al. 2010). In this respect, it is important to consider the remarkable characteristics of the carbonate chemistry of seawater from Ría Formosa lagoon. The TA is within the range observed in inner coastal waters of the southern Iberian Peninsula (Cabeçadas \& Oliveira 2005, De la Paz et al. 2007, 2008), which generally exceeds the values reported in previous ocean acidification perturbation experiments (Nisumaa et al. 2010, Range et al. 2011). This naturally elevated TA (around $3550 \mu \mathrm{mol} \mathrm{kg}{ }^{-1}$ ) prevented undersaturation of $\mathrm{CaCO}_{3}$, even in the $\mathrm{CO}_{2}$-acidified treatments, avoiding any significant impacts related to the carbonate supply. Instead, as suggested in a recent study with lobster larvae that reported a simi- lar buffering mechanism (Arnold 2008), the physiological alterations observed here were most likely the result of acidosis or hypercapnia interfering with normal homeostatic function.

Our study showed a significant increment in AE caused by seawater acidification (up to $72 \%$ in large mussels in the $\Delta \mathrm{pH}=-0.6$ treatment, see Table 2). This pattern may be related to the optimization of certain digestive enzymes (amylase, glucosidase and peptidase) under conditions of reduced $\mathrm{pH}$ (Wojtowicz 1972, Areekijseree et al. 2004), which could facilitate nutrient absorption. In agreement with the absorption efficiency (AE) response, the maximal SFG and tissue DW were observed for mussels exposed to the most extreme $\mathrm{pH}$ reduction $(\Delta \mathrm{pH}=$ $-0.6)$.

Intertidal species are usually equipped with compensatory physiological mechanisms that allow them to maintain homeostasis during tidal cycles (Montecinos et al. 2009). During periods of anaerobic metabolism there is a release of inorganic molecules (including $\mathrm{CaCO}_{3}$ from valves) into the pallial cavity of molluscs, in order to maintain the acid-base balance (Chaparro et al. 2009). J. Espinosa (unpubl. data) observed that the range of $\mathrm{pH}$ in the pallial fluid of Mytilus galloprovincialis under anaerobic conditions is $\sim 6.8$ to 7.2 , differing substantially from the average $\mathrm{pH}$ of seawater $(\sim 8.2)$. This suggests that the pallial fluid can act as an active compartment, which is involved in the physiological response of mussels. According to Pörtner et al. (2004), hypercapnia elicits a reduction in the aerobic metabolism of marine organisms as a result of acid-base disturbances. The metabolic response of mussels to the acidification of the pallial fluid and haemolymph (caused by the permanent acidification of the medium) could, therefore,

\begin{tabular}{|c|c|c|c|c|c|c|c|c|}
\hline $\begin{array}{l}\mathrm{AE} \\
(\%)\end{array}$ & $\begin{array}{l}\text { No. } \\
\text { ind. }\end{array}$ & $\begin{array}{c}V_{\mathrm{O} 2} \\
\left(\mathrm{ml} \mathrm{\textrm {O } _ { 2 }} \mathrm{h}^{-1}\right)\end{array}$ & $\begin{array}{c}V_{\mathrm{O} 2} \text { (specific) } \\
\left(\mu l \mathrm{O}_{2}(\mathrm{mg}\right. \\
\left.\mathrm{OW})^{-1} \mathrm{~h}^{-1}\right)\end{array}$ & $\begin{array}{l}\text { No. } \\
\text { ind. }\end{array}$ & $\begin{array}{l}V_{\mathrm{NH} 4-\mathrm{N}} \\
\left(\mu \mathrm{NH}_{4}\right. \\
\left.-\mathrm{N} \mathrm{h}^{-1}\right)\end{array}$ & $\begin{array}{c}V_{\mathrm{NH} 4-\mathrm{N}}(\text { specific }) \\
\left(\mu \mathrm{g} \mathrm{NH} \mathrm{NH}_{4}-\mathrm{N}\right. \\
\left.(\mathrm{mg} \mathrm{OW})^{-1} \mathrm{~h}^{-1}\right)\end{array}$ & $\begin{array}{c}\mathrm{O}: \mathrm{N} \\
\left(\mathrm{J} \mathrm{h}^{-1}\right)\end{array}$ & SFG \\
\hline $91.1 \pm 0.7$ & 50 & $0.4 \pm 0.1$ & $0.1 \pm 0.0$ & 50 & $27.8 \pm 1.7$ & $5.3 \pm 0.3$ & $16.6 \pm 2.0$ & $0.1 \pm 0.0$ \\
\hline $\begin{array}{c}59.2 \pm 1.3^{\mathrm{a}} \\
60.6 \pm 5.4^{\mathrm{a}} \\
\left(+56.1_{i}+72.1\right)\end{array}$ & $\begin{array}{l}30 \\
15\end{array}$ & $\begin{array}{l}0.1 \pm 0.0^{\mathrm{a}} \\
0.2 \pm 0.0^{\mathrm{b}}\end{array}$ & $\begin{array}{l}6.4 \pm 2.0^{\mathrm{a}} \\
6.2 \pm 0.6^{\mathrm{a}}\end{array}$ & $\begin{array}{l}30 \\
15\end{array}$ & $\begin{array}{c}20.3 \pm 1.5^{\mathrm{a}} \\
24.0 \pm 1.3^{\mathrm{a}} \\
(+17.9 ;+59.6)\end{array}$ & $\begin{array}{l}1.1 \pm 0.1^{\mathrm{a}} \\
0.7 \pm 0.0^{\mathrm{b}}\end{array}$ & $\begin{array}{r}7.6 \pm 1.2^{\mathrm{a}} \\
12.0 \pm 1.8^{\mathrm{b}}\end{array}$ & $\begin{array}{r}2.7 \pm 0.2^{\mathrm{a}} \\
10.1 \pm 1.5^{\mathrm{b}}\end{array}$ \\
\hline $\begin{array}{c}38.6 \pm 2.4^{\mathrm{b}} \\
41.6 \pm 3.0^{\mathrm{b}} \\
(+1.7 ;+18.4)\end{array}$ & $\begin{array}{l}30 \\
15\end{array}$ & $\begin{array}{l}0.1 \pm 0.0^{\mathrm{a}} \\
0.2 \pm 0.0^{\mathrm{b}}\end{array}$ & $\begin{array}{l}6.9 \pm 1.3^{\mathrm{a}} \\
6.4 \pm 0.2^{\mathrm{a}}\end{array}$ & $\begin{array}{l}30 \\
15\end{array}$ & $\begin{array}{c}19.5 \pm 2.8^{\mathrm{a}} \\
22.3 \pm 1.9^{\mathrm{a}} \\
(+13.1 ;+48.6)\end{array}$ & $\begin{array}{l}1.1 \pm 0.2^{\mathrm{a}} \\
0.7 \pm 0.1^{\mathrm{b}}\end{array}$ & $\begin{array}{r}7.7 \pm 1.9^{\mathrm{a}} \\
12.9 \pm 2.1^{\mathrm{b}}\end{array}$ & $\begin{array}{l}0.3 \pm 0.1^{\mathrm{c}} \\
4.3 \pm 1.0^{\mathrm{d}}\end{array}$ \\
\hline $\begin{array}{l}37.9 \pm 4.4^{\mathrm{bc}} \\
35.2 \pm 7.6^{\mathrm{c}}\end{array}$ & $\begin{array}{l}30 \\
15\end{array}$ & $\begin{array}{l}0.1 \pm 0.0^{\mathrm{a}} \\
0.3 \pm 0.0^{\mathrm{b}}\end{array}$ & $\begin{array}{l}6.4 \pm 2.0^{\mathrm{a}} \\
6.9 \pm 0.8^{\mathrm{a}}\end{array}$ & $\begin{array}{l}30 \\
15\end{array}$ & $\begin{array}{l}17.2 \pm 4.5^{\mathrm{b}} \\
15.0 \pm 3.1^{\mathrm{b}}\end{array}$ & $\begin{array}{l}0.8 \pm 0.3^{b} \\
0.7 \pm 0.2^{b}\end{array}$ & $\begin{array}{r}6.3 \pm 1.9^{\mathrm{a}} \\
14.1 \pm 2.3^{\mathrm{b}}\end{array}$ & $\begin{array}{l}0.4 \pm 0.1^{\mathrm{c}} \\
3.5 \pm 0.8^{\mathrm{d}}\end{array}$ \\
\hline
\end{tabular}


Table 3. Mytilus galloprovincialis. Two-way ANOVA testing the physiological parameters in mussels exposed to different values of $\mathrm{pH}$. O:N: ratio of oxygen consumed to nitrogen excreted; ns: not significant; ${ }^{*} \mathrm{p}<0.05 i^{* *} \mathrm{p}<0.01 i^{* * *} \mathrm{p}<0.001$

\begin{tabular}{|c|c|c|c|c|}
\hline Source & $\begin{array}{c}\text { Sum of } \\
\text { squares }\end{array}$ & $\mathrm{df}$ & $\begin{array}{c}\text { Mean } \\
\text { square }\end{array}$ & $F$-ratio \\
\hline \multicolumn{5}{|l|}{ Dry weight } \\
\hline $\mathrm{pH}$ & 95.1 & 2 & 47.5 & $4.0^{*}$ \\
\hline Size & 1374.4 & 1 & 1374.4 & $115.7^{* * *}$ \\
\hline $\mathrm{pH} \times$ Size & 33.7 & 2 & 16.8 & $1.4^{\mathrm{ns}}$ \\
\hline Error & 142.6 & 12 & 11.9 & \\
\hline \multicolumn{5}{|c|}{ Clearance rate } \\
\hline $\mathrm{pH}$ & $7.2 \times 10^{3}$ & 2 & $3.6 \times 10^{3}$ & $1.4^{\mathrm{ns}}$ \\
\hline Size & $1223.9 \times 10^{3}$ & 1 & $1223.9 \times 10^{3}$ & $474.4^{* * *}$ \\
\hline $\mathrm{pH} \times$ Size & $0.5 \times 10^{3}$ & 2 & $0.3 \times 10^{3}$ & $0.1^{\mathrm{ns}}$ \\
\hline Error & $30.9 \times 10^{3}$ & 12 & $2.5 \times 10^{3}$ & \\
\hline \multicolumn{5}{|c|}{ Ingestion rate organic } \\
\hline $\mathrm{pH}$ & $3.6 \times 10^{3}$ & 2 & $1.8 \times 10^{3}$ & $0.3^{\text {ns }}$ \\
\hline Size & $1609.6 \times 10^{3}$ & 1 & $1609.6 \times 10^{3}$ & $319.2^{* * *}$ \\
\hline $\mathrm{pH} \times$ Size & $18.8 \times 10^{3}$ & 2 & $9.4 \times 10^{3}$ & $1.8^{\mathrm{ns}}$ \\
\hline Error & $60.5 \times 10^{3}$ & 12 & $5.0 \times 10^{3}$ & \\
\hline \multicolumn{5}{|c|}{ Absorption efficiency } \\
\hline $\mathrm{pH}$ & $2.0 \times 10^{3}$ & 2 & $1.0 \times 10^{3}$ & $73.2^{* * *}$ \\
\hline Size & 0.6 & 1 & 0.6 & $0.0^{\mathrm{ns}}$ \\
\hline $\mathrm{pH} \times$ Size & 55.2 & 2 & 27.6 & $2.0^{\mathrm{ns}}$ \\
\hline Error & 165.2 & 12 & 13.7 & \\
\hline \multicolumn{5}{|c|}{ Metabolic rate $\left(V_{\mathrm{O} 2}\right)$} \\
\hline $\mathrm{pH}$ & 0.000 & 2 & 0.000 & $0.017^{\mathrm{ns}}$ \\
\hline Size & 0.053 & 1 & 0.053 & $36.242^{* * *}$ \\
\hline $\mathrm{pH} \times$ Size & 0.000 & 2 & 0.000 & $0.162^{\text {ns }}$ \\
\hline Error & 0.018 & 12 & 0.001 & \\
\hline \multicolumn{5}{|c|}{ Ammonia excretion rate $\left(V_{\mathrm{NH} 4-\mathrm{N}}\right)$} \\
\hline $\mathrm{pH}$ & 53.8 & 2 & 26.9 & $4.2^{*}$ \\
\hline Size & 16.1 & 1 & 16.1 & $2.5^{\mathrm{ns}}$ \\
\hline $\mathrm{pH} \times$ Size & 8.6 & 2 & 4.3 & $0.7^{\mathrm{ns}}$ \\
\hline Error & 77.0 & 12 & 0.4 & \\
\hline \multicolumn{5}{|l|}{ O:N index } \\
\hline $\mathrm{pH}$ & 0.939 & 2 & 0.469 & $0.083^{\mathrm{ns}}$ \\
\hline Size & 152.193 & 1 & 152.193 & $26.979^{* * *}$ \\
\hline $\mathrm{pH} \times$ Size & 9.616 & 2 & 4.888 & $0.852^{\text {ns }}$ \\
\hline Error & 67.694 & 12 & 5.641 & \\
\hline \multicolumn{5}{|c|}{ Scope for growth (SFG) } \\
\hline $\mathrm{pH}$ & 72.325 & 2 & 36.163 & $22.231^{* * *}$ \\
\hline Size & 105.173 & 1 & 105.173 & $64.656^{* * *}$ \\
\hline $\mathrm{pH} \times$ Size & 15.583 & 2 & 7.792 & $4.790^{* *}$ \\
\hline Error & 19.500 & 12 & 1.627 & \\
\hline
\end{tabular}

be similar to the response of intertidal individuals to anaerobic conditions.

According to De Zwaan et al. (1976), a pH decrease in the internal fluids causes a shift of mussel metabolism to partial anaerobiosis, with a consequent degradation of proteins. Due to the experimental design of this study, metabolic conditions of partial anaerobiosis were probably achieved, inducing the mussels to move from a state of anabolism to catabolism. Our results show significant differences in the excretion of ammonia $\left(V_{\mathrm{NH} 4-\mathrm{N}}\right)$ by Mytilus galloprovincialis, caused by the $\mathrm{pH}$ reductions, with larger values measured in mussels exposed to the most extreme $\mathrm{pH}$ reduction $(\Delta \mathrm{pH}=-0.6)$. This increase in $\mathrm{NH}_{4}$ excretion under reduced $\mathrm{pH}$ conditions can be interpreted as an intracellular $\mathrm{pH}$ regulatory mechanism. In fact, according to Boron (2004), greater excretion and protein degradation may support the production of $\mathrm{HCO}_{3}{ }^{-}$and, consequently, promote $\mathrm{pH}$ regulation. Also, Michaelidis et al. (2005), suggested that short-term (20 to $24 \mathrm{~h}$ ) incubation of M. galloprovincialis under acidified conditions resulted in an increased excretion of ammonia, indicating net degradation of proteins. Thomsen \& Melzner (2010) observed that $\mathrm{NH}_{4}{ }^{+}$excretion in $M$. edulis rose with increasing $\mathrm{pCO}_{2}$, and concluded that the decreased O:N ratios observed at the highest seawater $\mathrm{pCO}_{2}$ indicated enhanced protein metabolism, which contributed to intracellular $\mathrm{pH}$ regulation.

Overall, these results suggest that Mytilus galloprovincialis could be a tolerant ecophysiotype to $\mathrm{CO}_{2}$ acidification, at least in highly alkaline coastal waters. Nevertheless, mytilids are also able to dominate habitats with low alkalinity and high $\mathrm{pCO}_{2}$ (Thomsen et al. 2010). The mechanisms by which these mussels are able to compensate their physiological responses (i.e. increased ammonium excretion and absorption efficiency) to long-term exposure to acidified seawater are probably the same as those which explain their versatility in aerobic and anaerobic environments. According to Kroeker et al. (2010), the biological effects of ocean acidification are generally large and negative, but the variation in sensitivity amongst organisms has important implications for ecosystem responses. Accordingly, given the widespread presence of $M$. galloprovincialis in many coastal systems worldwide, its physiological behaviour might be pre-adapted to cope with future ocean acidification scenarios.

Acknowledgements. The authors thank the following persons for their help at various stages of this study: L. Nieto and B. Gonzalez for their valuable technical assistance; D. Matias, S. Joaquim and M. Ramos for producing microalgal food; and A. Leitão, D. Piló and M. Teixeira for keeping the system functioning. This is a contribution to the 'The integrated impacts of marine acidification, temperature and precipitation changes on bivalve coastal biodiversity and fisheries: how to adapt?' project, which is part of the CIRCLE Med projects, funded by the Regional Ministry of Innovation and Industry of the Galician Government (08MDS 018402PR), the Italian Ministry for Environment, Land and Sea, and the Foundation for Science and Technology of Portugal (ERA-CIRCLE/0004/2007), in the framework of the Circle ERA Net project (which is funded by the European Commission 6th Framework Programme). 


\section{LITERATURE CITED}

Anestis A, Pörtner HO, Karagiannis D, Angelidis P, Staikou A, Miachaelidis B (2010) Response of Mytilus galloprovincialis (L.) to increasing seawater temperature and to marteliosis: Metabolic and physiological parameters. Comp Biochem Physiol A 156:57-66

> Areekijseree M, Arunee E, Kovitvadhi U, Thongpan A, Mingmuang $\mathrm{M}$, Pakkong $\mathrm{P}$, Rungruangsak-Torrissen $\mathrm{K}$ (2004) Temperature and pH characteristics of amylase and proteinase of adult freshwater pearl mussel, Hyriopsis (Hyriopsis) bialatus (Simpson 1900). Aquaculture 234: 575-587

> Arnold WS (2008) Application of larval release for restocking and stock enhancement of coastal marine bivalve populations. Rev Fish Sci 16:65-71

Babarro JMF, Fernández-Reiriz MJ, Labarta U (2000a) Feeding behavior of seed mussel Mytilus galloprovincialis: environmental parameters and seed origin. J Shellfish Res 19:195-201

> Babarro JMF, Fernández-Reiriz MJ, Labarta U (2000b) Metabolism of the mussel Mytilus galloprovincialis from two origins in the Ría de Arousa (north-west Spain). J Mar Biol Assoc UK 80:865-872

Bamber NR (1990) The effects of acidic sea water on three species of lamellibranch molluscs. J Exp Mar Biol Ecol 143:181-191

Bayne BL, Brown DA, Burns K, Dixon DR and others (1985) The effects of stress and pollution on marine animals. Praeger, New York, NY

> Beesley A, Lowe DA, Pascoe CK, Widdicombe S (2008) Effects of $\mathrm{CO}_{2}$-induced seawater acidification on the health of Mytilus edulis. Clim Res 37:215-225

Berge JA, Bjerkeng B, Pettersen O, Schaanning MT, Oxnevad S (2006) Effects of increased sea water concentrations of $\mathrm{CO}_{2}$ on growth of the bivalve Mytilus edulis L. Chemosphere 62:681-687

Bibby R, Widdicombe S, Parry H, Spicer JI, Pipe R (2008) Impact of ocean acidification on the immune response of the blue mussel Mytilus edulis. Aquat Biol 2:67-74

- Boron WF (2004) Regulation of intracellular pH. Adv Physiol Educ 28:160-179

Cabeçadas L, Oliveira AP (2005) Impact of a Coccolithus braarudii bloom on the carbonate system of Portuguese coastal waters. J Nannoplankt Res 27:141-147

> Chaparro OR, Montory JA, Segura CJ, Pechenik JA (2009) Effect of reduced $\mathrm{pH}$ on shells of brooded veligers in the estuarine bivalve Ostrea chilensis Philippi 1845. J Exp Mar Biol Ecol 377:107-112

> Comeau S, Jeffree R, Teyssie JL, Galluso JP (2010) Response of the arctic pteropod Limacina helicina to projected future environmental conditions. PLoS ONE 5:e11362

> Conover RJ (1966) Assimilation of organic matter by zooplankton. Limnol Oceanogr 11:338-345

> Cooley SR, Doney SC (2009) Anticipating ocean acidification's economic consequences for commercial fisheries. Environ Res Lett 4:024007

> De la Paz M, Gómez-Parra A, Forja J (2007) Inorganic carbon dynamic and air-water $\mathrm{CO}_{2}$ exchange in the Guadalquivir Estuary (SW Iberian Peninsula). J Mar Syst 68:265-277

> De la Paz M, Gómez-Parra A, Forja J (2008) Tidal-to-seasonal variability in the parameters of the carbonate system in a shallow tidal creek influenced by anthropogenic inputs, Rio San Pedro (SW Iberian Peninsula). Cont Shelf Res 28:1394-1404
De Zwaan A, Kluytmans JHFM, Zandee DI (1976) Facultative anaerobiosis in molluscs. In: Smellie RMS, Pennock JF (eds) Biochemical adaptation to environmental change. Biochem Soc Symp 41:133-168

- Fabricius KE, Langdon C, Uthicke S, Humphrey C and others (2011) Losers and winners in coral reefs acclimatized to elevated carbon dioxide concentrations. Nature Clim Change 1:165-169

Fabry VJ, Seibel BA, Feely RA, Orr JC (2008) Impacts of ocean acidification on marine fauna and ecosystem processes. ICES J Mar Sci 65:414-432

> Feely RA, Sabine CL, Lee K, Berelson W, Kleypas J, Fabry VJ, Millero FJ (2004) Impact of anthropogenic $\mathrm{CO}_{2}$ on the $\mathrm{CaCO}_{3}$ system in the oceans. Science 305:362-366

> Fernández-Reiriz MJ, Range P, Alvarez-Salgado XA, Labarta U (2011) Physiological energetics of juvenile clams Ruditapes decussatus in a high $\mathrm{CO}_{2}$ coastal ocean. Mar Ecol Prog Ser 433:97-105

Filgueira R, Labarta U, Fernández-Reiriz MJ (2006) Flowthrough chamber method for clearance rate measurements in bivalves: design and validation of individual chambers and mesocosm. Limnol Oceanogr Methods 4: 284-292

Gazeau F, Quiblier C, Jansen JM, Gattuso JP, Middelburg JJ, Heip CHR (2007) Impact of elevated $\mathrm{CO}_{2}$ on shellfish calcification. Geophys Res Lett 34:L07603. doi:10.1029/ 2006GL028554

> Gazeau F, Gattuso JP, Dawver C, Proker AE and others (2010) Effect of ocean acidification on the early life stages of the blue mussel (Mytilus edulis). Biogeosciences 7:2051-2060

Gutowska MA, Pörtner HO, Melzner F (2008) Growth and calcification in the cephalopod Sepia officinalis under elevated seawater $\mathrm{pCO}_{2}$. Mar Ecol Prog Ser 373:303-309

Hall-Spencer JM, Rodolfo-Metalpa R, Martin S, Ransome E and others (2008) Volcanic carbon dioxide vents show ecosystem effects of ocean acidification. Nature 454: 96-99

Ivlev VS (1966) The biological productivity of waters. J Fish Res Board Can 23:1727-1759

Kleypas JA, Feely RA, Fabry VJ, Langdon C, Sabine CL, Robbins LL (2006) Impacts of ocean acidification on coral reefs and other marine calcifiers. A guide for future research. Report of a workshop. University Corporation for Atmospheric Research; California State University; University of Miami. Retrieved from www.ucar.edu/ communications/Final_acidification.pdf

Koch R, Gobler CJ (2009) The effects of tidal export from salt marsh ditches on estuarine water quality and plankton communities. Est Coasts 32:261-275

Kroeker KJ, Kordas RL, Crim RN, Singh GG (2010) Metaanalysis reveals negative yet variable effects of ocean acidification on marine organisms. Ecol Lett 13:1419-1434

Kurihara $\mathrm{H}$ (2008) Effects of $\mathrm{CO}_{2}$-driven ocean acidification on the early developmental stages of invertebrates. Mar Ecol Prog Ser 373:275-284

> Labarta U, Fernández-Reiriz MJ, Babarro JMF (1997) Differences in physiological energetics between intertidal and raft cultivated mussels Mytilus galloprovincialis. Mar Ecol Prog Ser 152:167-173

> Melzner F, Gutowska MA, Langenbuch M, Dupont S and others (2009) Physiological basis for high $\mathrm{CO}_{2}$ tolerance in marine ectothermic animals: pre-adaptation through lifestyle and ontogeny? Biogeosciences 6:2313-2331

> Michaelidis B, Ouzounis C, Paleras A, Pörtner HO (2005) 
Effects of long-term moderate hypercapnia on acid-base balance and growth rate in marine mussels Mytilus galloprovincialis. Mar Ecol Prog Ser 293:109-118

Miller AW, Reynolds AC, Sobrino C, Riedel GF (2009) Shellfish face uncertain future in high $\mathrm{CO}_{2}$ world: Influence of acidification on oyster larvae and growth in estuaries. PLoS One 4:e5661

Montecinos LA, Cisterna JA, Cáceres CW, Saldías GS (2009) Equilibrio ácido-base durante la exposición aérea en el molusco bivalvo Perumytilus purpuratus (Lamarck, 1819) (Bivalvia: Mytilidae). Rev Biol Mar Oceanogr 44:181-187

Nisumaa AM, Pesant S, Bellerby RGJ, Delille B and others (2010) EPOCA/EUR-OCEANS data compilation on the biological and biogeochemical responses to ocean acidification. Earth Syst Sci Data 2:167-175

> Orr JC, Fabry VJ, Aumont O, Bopp L and others (2005) Anthropogenic ocean acidification over the twenty-first century and its impact on calcifying organisms. Nature 437:681-686

Pauly D, Christensen V, Guenette S, Pitcher TJ and others (2002) Towards sustainability in world fisheries. Nature 418:689-695

Pörtner HO (2008) Ecosystem effects of ocean acidification in times of ocean warming: a physiologist's view. Mar Ecol Prog Ser 373:203-217

Pörtner HO, Langenbuch M, Reipschläger A (2004) Biological impact of elevated ocean $\mathrm{CO}_{2}$ concentrations: Lessons from animal physiology and earth history. J Oceanogr 60:705-718

Range P, Chicharo MA, Ben-Hamadou R, Piló D and others (2011) Calcification, growth and mortality of juvenile clams Ruditapes decussatus under increased $p \mathrm{CO} 2$ and reduced $\mathrm{pH}$ : variable responses to ocean acidification at local scales? J Exp Mar Biol Ecol 396:177-184

Ries B, Cohen AL, McCorkle DC (2009) Marine calcifiers exhibit mixed responses to $\mathrm{CO}_{2}$ induced ocean acidification. Geol Soc Am 37:1131-1134

Rodolfo-Metalpa R, Houlbrèque F, Tambutté E, Boisson F and others (2011) Coral and mollusc resistance to ocean acidification adversely affected by warming. Nature

Editorial responsibility: James McClintock,

Birmingham, Alabama, USA
Clim Change 1:308-312

Salisbury J, Green M, Hunt C, Campbell J (2008) Coastal acidification by rivers: A new threat to shellfish? EOS Trans Am Geophysl Union 89:513

Saphörster J (2008) The physiology of the blue mussel (Mytilus edulis) in relation to ocean acidification. Diplomarbeit, Rostock University

Snedecor GW, Cochran WG (1980) Statistical methods. Iowa State University Press, Ames, IA

Solorzano L (1969) Determination of ammonia in natural waters by the phenolhypochlorite method. Limnol Oceanogr 14:799-801

Talmage SC, Gobler CJ (2009) The effects of elevated carbon dioxide concentrations on the metamorphosis, size and survival of larval hard clams (Mercenaria mercenaria), bay scallops (Argopecten irradians), and Eastern oysters (Crassostrea virginica). Limnol Oceanogr 54: 2072-2080

Thomsen J, Melzner F (2010) Moderate seawater acidification does not elicit long-term metabolic depression in the blue mussel Mytilus edulis. Mar Biol 157:2667-2676

> Thomsen J, Gutowska MA, Saphörster J, Heinemann A and others (2010) Calcifying invertebrates succeed in a naturally $\mathrm{CO}_{2}$-rich coastal habitat but are threatened by high levels of future acidification. Biogeosciences Discuss 7 : 5119-5156

Widdows J (1985) Physiological measurements. In: Bayne BL, Brown DA, Burns K, Dixon DR and others (eds) The effects of stress and pollution on marine animals. Praeger, New York, NY, p 3-45

Winberg GC (1960) Rate of metabolism and food requirements of fishes. Fish Res Board Canada Trans Ser 194

- Wojtowicz MB (1972) Carbohydrases of the digestive gland and the crystalline style of the atlantic deep-sea scallop (Placopecten magellanicus, Gmelin). Comp Biochem Physiol A 43:131-141

Wood HL, Spicer JI, Widdicombe S (2008) Ocean acidification may increase calcification rates, but at a cost. Proc Biol Sci 275:1767-1773

Zar JH (1984) Biostatistical analysis. Prentice Hall, Englewood Cliffs, NJ

Submitted: September 7, 2011; Accepted: February 6, 2012 Proofs received from author(s): April 27, 2012 